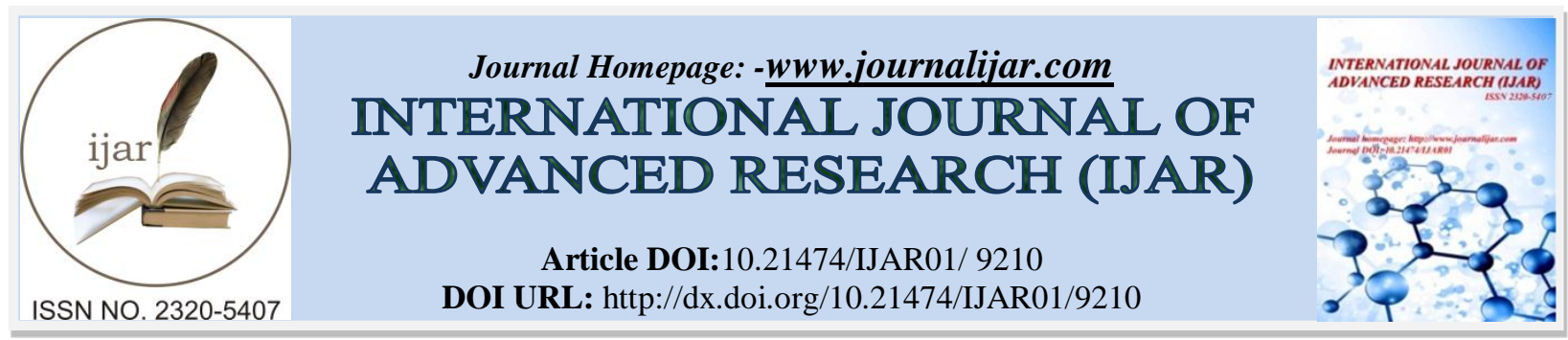

RESEARCH ARTICLE

\title{
YIELD PENALTY ASSOCIATED WITH STACKING RESISTANCE TO LATE LEAF SPOT, ROSETTE DISEASES AND DROUGHT STRESS IN GROUNDNUT (ARACHIS HYPOGAEA L.)
}

\section{Khalid Elsiddig Mohammed ${ }^{1}$, Eric E. Agoyi ${ }^{4}$, Thomas L. Odong ${ }^{1}$, Belay Miesho ${ }^{3}$, David K. Okello ${ }^{2}$, Olupot}

Giregon $^{1}$, Patrick R. Rubaihayo ${ }^{1}$ and Patrick Okori ${ }^{1}$.

1. College of Agriculture and Environmental Sciences, Makerere University, P. O. Box 7062, Kampala, Uganda.

2. Department of Groundnut Breeding, National Semi-Arid Research Resources Institute, P. O. Box Soroti, Uganda.

3. College of Agriculture, Aksum University-Shire campass, P.O.Box 314, Shire, Ethiopia.

4. Non Timber Forest Products \& Orphan Crop UNIT, Laboratory of Applied Ecology, University of Abomeycalavi, 05 P.O Box 1752 Cotonou, Bénin.

\section{Manuscript Info}

\section{Manuscript History}

Received: 05 April 2019

Final Accepted: 07 May 2019

Published: June 2019

Key words:-

Peanut, production, biotic, abiotic, infections.

\section{Abstract}

Groundnut production is constrained by late leaf spot, groundnut rosette disease and drought which are responsible for up to $100 \%$ yield loss. This study was conducted to determine yield penalty associated with stacking resistance to late leaf spot, rosette and drought stress in groundnut genotypes. Twenty eight genotypes comprising single, double and multiple resistances for the diseases and tolerant to drought were evaluated in screen houses at Namulonge and Kabanyolo, in 2017. Completely randomized design was used in two replications. Three watering regimes were applied. Diseases severity was scored at harvest based on 1-9 scale. Drought was assessed with relative water content and leaf membrane stability index. Yield penalty was calculated as yield of the resistant genotype under optimum conditions minus yield of the same genotype under stress. The results of analysis of variance showed significant difference $(P<0.001)$ from one location to another and genotype-by-location effect was significant for most traits. The highest pod yield was observed at optimum conditions and under disease control, while the lowest was observed under the combination of diseases and drought. The highest yield penalty (19.98) was recorded by rosette resistant genotype SGV 0007. Low yield penalty (6.6), due to leaf spot and rosette diseases, was observed for genotype Abutalata. Penalty was positively correlated $(r=0.24)$ with relative water content and rosette and negatively correlated with leaf spot. Genotypes which showed low yield penalty could be valuable genetic materials for breeding of groundnut resistance to multiple stresses in Uganda or similar environments.

Copy Right, IJAR, 2019,. All rights reserved. 


\section{Introduction:-}

Groundnut (Arachis hypogaea L.) production is constrained by several biotic stresses (Maiti, 2002). These include foliar fungal diseases such as early leaf spot (ELS) caused by Cercospora arachidicola Hori, late leaf spot (LLS) caused by Cercospora personata Berk \& Curt and rust caused by Puccinia arachidis Speg (Subrahmanyam et al., 1985); viral diseases such as groundnut rosette disease (GRD), peanut bud necrosis and stem necrosis (Lynch, 1990) and soil-borne diseases such as stem rot, collar rot and pod rot complexes are the most prevailing diseases in East and Central Africa (Okello et al., 2010). In Uganda, fungal diseases, particularly late leaf spot is the key constraint which affects the production of groundnut and results in up to 70\% yield reduction (Okello et al., 2013). Also GRD is the most destructive disease to the groundnut production, and it can cause yield losses of up to 100\% depending on the growth stage at which infection occurs (Okello et al., 2010). In addition to biotic stresses, groundnut is mainly grown under rain-fed conditions and its production depends on rainfall and rain distribution that are usually unpredictable (Reddy et al., 2003). The unpredictability of drought implies that improved groundnut genotypes should perform well not only under water limited conditions, but also when rainfall is adequate. Drought stress has adverse influence on water relations (Babu and Rao, 1983), photosynthesis (Bhagsari et al., 1976), growth and yield of groundnut (Suther and Patel, 1992) and relative water content and rate of transpiration of the groundnut (Kambiranda et al., 2011). This results in a drastic reduction of crop yield, depending on groundnut cultivars. Varieties producing high yield under drought conditions are thus required.

Breeding for high-yielding, foliar disease resistant genotypes requires identification of resistant cultivars with good breeding potential. It is possible to combine resistance to more than one disease in the same genetic background (Anderson et al., 1986), since the resistance to the different diseases is under different genes action. Unfortunately, many traits that are associated with resistance to pathogens reduce plant fitness, although others do not (Bergelsen, 1996). In a case study carried out in Germany, the resistant varieties possessed a lower yield potential than susceptible ones under disease-free conditions (BSA, 2012). Less susceptible varieties yielded about 5-7\% lower than the highest-yielding susceptible varieties under disease-free conditions (Gummert et al., 2015). Mechelke, (2000) reported that resistant varieties presented 10-18\% yield penalty in the absence of the pathogen, and thus too low to gain acceptance for cultivation on a large scale on commercial farms.

When genetic resistance is incorporated into cultivars against prevailing biotic and abiotic stresses, there is usually cost on yield potential (Knauft and Wynne, 1995) as cultivars that maximize stress tolerance tend to pay a penalty in yield production (Zavaleta et al., 2010). The costs of resistance contain some of the negative effects on plant fitness that may be caused by a resistance trait under natural growing conditions (Heil, 2002). Moderate to high resistance to LLS, GRD and drought have been developed in numerous groundnut genotypes. There is lack of understanding of the effect/cost of these diseases resistance genes and drought tolerance genes on groundnut yield. Therefore, this study was conducted to determine yield penalty associated with stacking resistance to LLS, GRD and drought stress in groundnut.

\section{Materials And Methods:}

\subsection{Plant materials and experimental design}

Twenty eight groundnut genotypes including parents and crosses showing single, double and multiple resistance to LLS, GRD and drought were exposed to artificial infestations with the diseases and drought stress according to their resistance capacity (Table 1). The experiments were carried out in the screen houses at National Crop Research Resources Institute (NaCRRI) and Makerere University Agricultural Research Institute Kabanyolo (MUARIK) between $11^{\text {th }}$ January and $10^{\text {th }}$ may 2017. Three watering regimes: $80 \%$ (T1), $60 \%$ (T2) and 40\% (T3) of soil field capacity (FC) were imposed based on moisture meter reading. The experiments were conducted in two replications using completely randomized design. The controls were irrigated with $80 \%$ FC (T1) with no disease infestation.

\subsection{Infestation with Groundnut Rosette Disease (GRD)}

Greenhouse infestation with virulent aphids was done following the method developed by Kayondo, et al (2014). Aphids were obtained from groundnut plants infested with GRD from the field as evidenced by green and chlorotic rosette symptoms and were transferred on to disease free plants of susceptible genotypes JL 24 and Acholi white, 14 days after planting in the cages for mass rearing and for maintenance of large stocks of virulent aphids needed for artificial infestation during the experiment. Two weeks after germination of the experimental plants, infector rows (Acholi-white and JL-24) were placed between each two rows of the tested genotypes and aphids were free to move and find suitable plant hosts. 


\subsection{Infestation with late leaf spot (LLS)}

Infested leaf debris with Cercospora personata was collected from the field and stored in cloth bags in farm shed for the use in the experiments. Spores were prepared from the stored debris (Hemantkumar, 2005) and sprayed uniformly 15 days after planting following the method developed by Ibrahim, (2010).

Table 1: Description of 28 groundnut genotypes assessed for yield penalty associated with resistance to late leaf spot (LLS), rosette disease (GRD) and drought tolerance (D)

\begin{tabular}{|c|c|c|c|c|}
\hline Resistance attribute & Specific resistance & Treatments & Genotype & Pedigree \\
\hline \multirow{8}{*}{ Single resistant } & \multirow{2}{*}{ LLS } & \multirow{2}{*}{ LLS } & ICGV 03590 & Parent \\
\hline & & & Serenut.1 & Parent \\
\hline & \multirow{2}{*}{ GRD } & \multirow{2}{*}{ GRD } & SGV 0007 & Parent \\
\hline & & & SGV 0074 & Parent \\
\hline & \multirow{4}{*}{ Drought (D) } & \multirow{4}{*}{ Drought (D) } & ICGV 01510 & Parent \\
\hline & & & SGV AWI. 0801 & Parent \\
\hline & & & SGV AWI.0802 & Parent \\
\hline & & & SGV AW .S6 & Parent \\
\hline \multirow{30}{*}{ Double resistant } & \multirow{6}{*}{ LLS + GRD } & \multirow{2}{*}{ LLS } & Serenut.2 & Parent \\
\hline & & & SGV 0005 & Parent \\
\hline & & \multirow{2}{*}{ GRD } & Serenut.2 & Parent \\
\hline & & & SGV 0005 & Parent \\
\hline & & \multirow{2}{*}{ LLS + GRD } & Serenut.2 & Parent \\
\hline & & & SGV 0005 & Parent \\
\hline & \multirow{24}{*}{$\mathrm{LLS}+\mathrm{D}$} & \multirow{12}{*}{ LLS } & SGV AWI. 0803 & Parent \\
\hline & & & SGV AWI. 0804 & Parent \\
\hline & & & SGV $0803 \times$ Abutalata (C3) & Cross \\
\hline & & & SGV $0804 \times$ Abutalata $(\mathrm{C} 4)$ & Cross \\
\hline & & & SGV S.6txAW x Abutalata (C5) & Cross \\
\hline & & & SGV $01510 \times$ Abutalata (C6) & Cross \\
\hline & & & SGV 0801 x SGV 03590 (C7) & Cross \\
\hline & & & SGV 0802 x SGV $03590(\mathrm{C} 8)$ & Cross \\
\hline & & & SGV 0803 x SGV 03590 (C9) & Cross \\
\hline & & & SGV 0804 x SGV 03590 (C10) & Cross \\
\hline & & & SGV S.6txAW x SGV 03590 (C11) & Cross \\
\hline & & & SGV 01510 x SGV 03590 (C12) & Cross \\
\hline & & \multirow{12}{*}{$\mathrm{D}$} & SGV AWI. 0803 & Parent \\
\hline & & & SGV AWI. 0804 & Parent \\
\hline & & & SGV $0803 \times$ Abutalata (C3) & Cross \\
\hline & & & SGV $0804 \times$ Abutalata $(\mathrm{C} 4)$ & Cross \\
\hline & & & SGV S.6txAW x Abutalata (C5) & Cross \\
\hline & & & SGV $01510 \times$ Abutalata (C6) & Cross \\
\hline & & & SGV 0801 x SGV 03590 (C7) & Cross \\
\hline & & & SGV 0802 x SGV $03590(\mathrm{C} 8)$ & Cross \\
\hline & & & SGV 0803 x SGV 03590 (C9) & Cross \\
\hline & & & SGV 0804 x SGV 03590 (C10) & Cross \\
\hline & & & SGV S.6txAW x SGV 03590 (C11) & Cross \\
\hline & & & SGV 01510 x SGV 03590 (C12) & Cross \\
\hline
\end{tabular}

\begin{tabular}{|c|c|c|c|c|}
\hline $\begin{array}{c}\text { Resistance } \\
\text { attribute }\end{array}$ & $\begin{array}{c}\text { Specific } \\
\text { resistance }\end{array}$ & Treatments & Genotype & Pedigree \\
\hline \multirow{2}{*}{$\begin{array}{c}\text { Double } \\
\text { resistant }\end{array}$} & LLS + D & \multirow{2}{*}{ LLS + D } & SGV 0803 x Abutalata (C3) & Cross \\
\cline { 3 - 4 } & & SGV 0804 x Abutalata (C4) & Cross \\
\cline { 3 - 4 } & & SGV S.6txAW x Abutalata (C5) & Cross \\
\cline { 3 - 4 } & & SGV 01510 x Abutalata (C6) & Cross \\
\hline
\end{tabular}




\begin{tabular}{|c|c|c|c|c|}
\hline & & & SGV 0801 x SGV $03590(C 7)$ & Cross \\
\hline & & & SGV 0802 x SGV 03590 (C8) & Cross \\
\hline & & & SGV 0803 x SGV 03590 (C9) & Cross \\
\hline & & & SGV 0804 x SGV 03590 (C10) & Cross \\
\hline & & & SGV S.6txAW x SGV $03590(\mathrm{C} 11)$ & Cross \\
\hline & & & SGV 01510 x SGV $03590(\mathrm{C} 12)$ & Cross \\
\hline & \multirow{6}{*}{$\mathrm{GRD}+\mathrm{D}$} & \multirow{2}{*}{ GRD } & SGV ER 10004 & Parent \\
\hline & & & SGV ER 10009 & Parent \\
\hline & & \multirow{2}{*}{$\mathrm{D}$} & SGV ER 10004 & Parent \\
\hline & & & SGV ER 10009 & Parent \\
\hline & & \multirow{2}{*}{ GRD + D } & SGV ER 10004 & Parent \\
\hline & & & SGV ER 10009 & Parent \\
\hline \multirow{27}{*}{$\begin{array}{l}\text { Multiple } \\
\text { resistant }\end{array}$} & \multirow{27}{*}{$\begin{array}{c}\mathrm{LLS}+\mathrm{GRD}+ \\
\mathrm{D}\end{array}$} & \multirow{4}{*}{ LLS } & Abutalata & Parent \\
\hline & & & SGV ER 10003 & Parent \\
\hline & & & SGV $0801 \times$ Abutalata (C1) & Cross \\
\hline & & & SGV 0802 x Abutalata (C2) & Cross \\
\hline & & & Abutalata & Parent \\
\hline & & & SGV ER 10003 & Parent \\
\hline & & GRD & SGV $0801 \times$ Abutalata (C1) & Cross \\
\hline & & & SGV $0802 \times$ Abutalata (C2) & Cross \\
\hline & & & Abutalata & Parent \\
\hline & & $\mathrm{D}$ & SGV ER 10003 & Parent \\
\hline & & D & SGV $0801 \times$ Abutalata (C1) & Cross \\
\hline & & & SGV $0802 \times$ Abutalata (C2) & Cross \\
\hline & & & Abutalata & Parent \\
\hline & & & SGV ER 10003 & Parent \\
\hline & & LLS + GRD & SGV $0801 \times$ Abutalata $(\mathrm{C} 1)$ & Cross \\
\hline & & & SGV $0802 \times$ Abutalata (C2) & Cross \\
\hline & & & SGV ER 10003 & Parent \\
\hline & & LLS+D & SGV $0801 \times$ Abutalata (C1) & Cross \\
\hline & & & SGV 0802 x Abutalata (C2) & Cross \\
\hline & & & Abutalata & Parent \\
\hline & & & SGV ER 10003 & Parent \\
\hline & & GRD + D & SGV $0801 \times$ Abutalata $(\mathrm{C} 1)$ & Cross \\
\hline & & & SGV $0802 \times$ Abutalata (C2) & Cross \\
\hline & & & Abutalata & Parent \\
\hline & & $\mathrm{II} \mathrm{S}+\mathrm{GRD} \perp \mathrm{D}$ & SGV ER 10003 & Parent \\
\hline & & LLS + GRD + D & SGV 0801 x Abutalata (C1) & Cross \\
\hline & & & SGV $0802 \times$ Abutalata (C2) & Cross \\
\hline
\end{tabular}

\subsection{Data collection}

Late leaf spot disease (LLS) severity scoring was done at harvesting based on a rating scale of increasing severity of $1-9$. Disease score 1 means $0 \%$ foliar infestation; 2 for $1-5 \%$; 3 for $6-10 \%$; 4 for $11-20 \%$; 5 for $21-30 \%$; 6 for $31-$ $40 \%$; 7 for $41-60 \%$; 8 for $61-80 \%$ and 9 for $81-100 \%$ of foliar area infection with plants having almost all leaves defoliated leaving bare stems (Subrahmanyam et al., 1995). Genotypes with a disease score 1-3 = resistant, 4-5= moderate resistance, $6-7=$ susceptible and 8-9 = highly susceptible (ICRISAT, 1995).

Groundnut rosette disease (GRD) severity was scored at harvest using a scale of 1-9 based on the intensity of disease attack (Okello et al., 2014), where $1=$ resistant with no symptom, $2=$ very slight leaf symptoms and $3=$ slight leaf 
symptoms but still negligible; 4-6 moderately resistant with leaf symptoms and no stunting [where $4=$ showed $50 \%$ symptoms on leaves, $5=$ all leaves showed symptom of chlorosis and 6 is $25 \%$ stunted]; $7-9=$ susceptible [where all leaves showed symptom of chlorosis, 7 showed $50 \%$ stunted, 8 and 9 severe leaf symptoms with > 50\% stunt where $8=$ had few pods while $9=$ no pod at all]. This rating scale was adopted from the Groundnut Improvement Programme at NaSARRI in Serere, Uganda (NaSARRI, unpublished).

Drought was assessed in terms of relative water content and leaf membrane stability index as follows: The relative water content (RWC) was recorded from four leaflets of the third fully expanded leaf from the top of the main stem for each pot two weeks after flowering according to Iqbal and Bano, (2009). The leaves were picked in the morning (9-11 a.m) and taken to the laboratory and leaf fresh weight (FW) recorded. Each leaf sample was soaked in distilled water for $8 \mathrm{hrs}$ and blotted for surface drying and water saturated leaf weight (TW) was recorded. The samples were then oven-dried at $60^{\circ} \mathrm{C}$ for $6 \mathrm{hrs}$ to a constant weight and leaf dry weight (DW) recorded. RWC was calculated based on the formula suggested by Gonzalez and Gonzalez (2001) as follows.

$\operatorname{RWC}(\%)=\frac{(F W-D W)}{(T W-D W)} \times 100$

Where:

FW is the sample fresh weight, TW is the sample turgid weight and DW is the sample oven dry weight.

The leaf membrane stability index (LMSI) was determined according to Sairam, (1994). Leaf discs (0.5g) from the third fully expanded leaflet collected at pod filling stage of uniform diameter were put in test tubes containing $10 \mathrm{ml}$ of double distilled water in two sets. Test tubes in one set were kept at $40^{\circ} \mathrm{C}$ in a water bath for 30 min and electrical conductivity of the sample was recorded $\left(\mathrm{C}_{1}\right)$ using an electric conductivity (EC) meter and the test tubes in the other set were incubated at $100^{\circ} \mathrm{C}$ in a water bath for $15 \mathrm{~min}$ and their EC recorded $\left(\mathrm{C}_{2}\right)$. LMSI was calculated using the formula proposed by Sairam, (1994).

Yield was assessed as Pod weight gram plant ${ }^{-1}$,

$$
\text { LMSI }=\frac{1-\mathrm{C} 1}{\mathrm{C} 2} \times 100
$$

yield penalty was calculated as follow:

Yield penalty $=$ yield of the resistant genotype under normal conditions - yield of the same resistant genotype under stress which is resistant according to James et al. (2010).

\subsection{Data analysis}

Analysis of variance (ANOVA) were performed in GENSTAT statistical package 16th edition (Payne et al., 2013). The means were separated using least significant difference (LSD).

\section{Results And Discussion:}

\subsection{Phenotypic Variability}

The results of analysis of variance among the 28 groundnut genotypes for late leaf spot (LLS), groundnut rosette disease (GRD), Drought (D) indexes, pod yield and yield penalty evaluated in two locations are presented in Table 2. The results showed highly significant difference $(\mathrm{P}<0.001)$ among genotype for all the traits studied except LLS score. High significant differences $(\mathrm{P}<0.01)$ was recorded by the locations except LLS and GRD. These differences indicated the presence of high genetic variability in the genotypes (Wambi, et al., 2014 and Mugisa et al., 2016) and locations for these traits. The highly significant $(\mathrm{P}<0.001)$ difference of genotype-by-location interactions for all traits except LLS and GRD and significant $(\mathrm{P}<0.01)$ variance due to genotype-by-treatment for RWC and pod weight this confirmed existence of wide variation among genotypes, locations and treatments.

Table 2: Mean sum of squares for drought, LLS and GRD severity at harvest, yield and yield penalty for 28 groundnut genotypes evaluated in Kabanyolo and Namulonge 2017

\begin{tabular}{|c|c|c|c|c|c|c|c|}
\hline SOV & Df. & RWC & LMSI & Pod wt & $\begin{array}{c}\text { Penalty pod } \\
\text { wt }\end{array}$ & $\begin{array}{c}\text { LLS at } \\
\text { harvest }\end{array}$ & $\begin{array}{c}\text { GRD at } \\
\text { harvest }\end{array}$ \\
\hline Rep & 1 & 10.55 & 180.7 & 38.946 & 113.06 & 0.24 & 0.14 \\
\hline Genotype(G) & 21 & $713.5 * * *$ & $218.05 * * *$ & $46.28 * * *$ & $129.31 * * *$ & 0.36 & $3.90 * * *$ \\
\hline Location(L) & 1 & $81991.38 * * *$ & $2573.11 * * *$ & $38.617 * *$ & $610.2 * * *$ & 0.53 & 1.24 \\
\hline Treatment(T) & 7 & $9710.61 * * *$ & $6900.35 * * *$ & $781.702 * * *$ & $209.46 * * *$ & & \\
\hline
\end{tabular}




\begin{tabular}{|c|c|c|c|c|c|c|c|}
\hline G x L & 21 & $601.33^{* * *}$ & $101.8 * * *$ & $57.209 * * *$ & $194.66^{* * *}$ & 0.08 & 0.12 \\
\hline G x T & 75 & $65.84 * * *$ & 56.47 & $8.216^{* *}$ & 3.93 & & \\
\hline L x T & 7 & $3227.64 * * *$ & $521.85^{* * *}$ & $82.541^{* * *}$ & 4.99 & & \\
\hline G x L x T & 75 & $77.07 * * *$ & $58.41^{* * *}$ & $8.479^{* * *}$ & 4.81 & & \\
\hline Residual & 207 & 31.62 & 42.81 & 5.455 & 20.03 & 0.30 & 0.73 \\
\hline CV\% & & 19.75 & 52.09 & 42.52 & 50.99 & 19.6 & 24.6 \\
\hline
\end{tabular}

SOV: Source of variation; Df: Degree of freedom; RWC: Relative water content; LMSI: Leaf membrane stability index; Pod wt: Pod weight (g); LLS: Late leaf spot score at harvest; GRD Severity: Groundnut rosette disease severity at harvest; CV\% Coefficient of variation; $* * *=$ Significant at .001; $* *=$ Significant at .01; Treatment (T): the water stress.

Similar findings were reported by Mugisa et al. (2016) who studied Determinants of groundnut rosette virus disease occurrence in Uganda and found that the disease severity and groundnut yields were significantly affected by location and genotype and their three way interactions. This variation implying that these genotypes consisted of a source of high yielding and resistance to LLS and GRD and drought tolerance with low yield penalty to be used for improvement of existing low yielding and susceptible groundnut varieties currently in use. The results also suggested that for the purpose of breeding, cultivars could be developed for different disease resistances and drought tolerance.

\subsection{Means of disease severity and drought tolerance of groundnut genotypes}

Means of resistance to late leaf spot (LLS) and groundnut rosette disease (GRD) severity at harvest and drought (D) tolerance for groundnut genotypes grown in the screen house at NaCRRI and MUARIK, 2017 are presented in Table 3. LLS severity at harvest for the studied resistant genotypes ranged between 2.25 for SGV 0005 and SGV $0804 \mathrm{x}$ SGV 03590-C10 and 3.5 for SGV $0802 \times$ Abutalata-C2 indicating that these genotypes were resistant (Subrahmanyam et al., 1995). The highest GRD severity observed, 5.25 for SGV 0803 x Abutalata-C3, 4.75 for SGV 0804 x Abutalata-C4, SGV S.6txAW x Abutalata-C5, SGV 01510 x Abutalata-C6 and SGV 0801 x SGV 03590-C7, followed by 4 for SGV S.6txAW x SGV 03590-C11 and 3.75 for SGV 0804 x SGV 03590-C10 and SGV 0802 x SGV 03590-C8 indicated that these genotypes were susceptible (Okello et al., 2014). The lowest score for GRD ranged between 2 for SGV ER 10003 and SGV 0801 x Abutalata-C1 and 3.5 for SGV 0803 x SGV 03590-C9 and SGV 01510 x SGV 03590-C12 indicating their resistance to GRD (Okello et al., 2014).

High relative water content (RWC) under drought showed by SGV AWI.0802, SGV AWI. 0804, SGV AWI. 0803, SGV ER 10004, SGV ER 10003 and SGV AWI. 0801 With values of $(44.02,43.655,43.585,42.35,42.22$ and 42.09 respectively) and leaf membrane stability index (LMSI) was high under drought in the drought tolerant genotypes (Abutalata, SGV 01510 x Abutalata-C6, and ICGV 01510) with values of 27.615, 22.475 and 21.555 respectively. These high RWC and LMSI indicated that these genotypes were tolerant to drought (Reddy et al., 2003). Similar findings were reported by Shinde and Laware, (2014) who studied groundnut varieties for drought tolerance through physiological indices and found RWC and LMSI were high among drought tolerant varieties as compared to susceptible ones.

\subsection{Means of pod yield of resistant genotypes to late leaf spot, rosette diseases and tolerant to drought}

High pod weight $\left(12.8 \mathrm{~g} \mathrm{plant}^{-1}\right)$ was observed by Serenut 1 single resistance to late leaf spot under normal conditions (Fig 1.A). The high pod weight 15.55 and 12.85 observed by double resistance to LLS+GRD genotypes viz, Serenut.2 and SGV 0005 respectively under $80 \%$ water field capacity (Fig 2.A). High pod weight (18.87) was observed by the double resistant genotypes (SGV 01510 x SGV 03590-C12) to LLS+D under control (Fig 2.C). The lowest pod weight (0.95) observed under LLS +GRD+T2 was recorded by SGV 0801 x Abutalata-C1 (Fig 6.B) followed by Serenut.2 (1.43) under LLS+GRD infestation (Fig 2.A). This high yield under control and non waterstressed (T1) and low yield observed under the high stress level of three combinations of stresses indicate the effect of diseases and drought on groundnut yield. Similar finding was reported by Mohammed et al. (2018) who studied sources of resistance to LLS, GRD and yield potential and found low yield performance under severe late leaf spot and groundnut rosette disease. On the other hand, Hamidou et al. (2012) evaluated groundnut under drought stress for yield component and found $72 \%$ decreased pod yield due to drought. This suggest that these resistant genotypes with low pod yield under stress spent more energy in resistance than yield, similar conclusion was drawn by Nigam et al. (1991). This yield loss due to resistance against biotic and abiotic stresses is called yield penalty (Mechelke, 2000). 
Table 3:-Means for LLS and GRD severity score and drought traits of 28 groundnut genotypes evaluated at NaCRRI and MUARIK 2017

\begin{tabular}{|c|c|c|c|c|c|c|c|c|c|c|c|c|c|c|}
\hline \multirow{3}{*}{ Genotype } & \multirow{3}{*}{$\begin{array}{l}\text { LLS } \\
\text { Score }\end{array}$} & \multirow{3}{*}{$\begin{array}{l}\text { GRD } \\
\text { Score }\end{array}$} & \multicolumn{6}{|c|}{ Water stress } & \multirow{2}{*}{\multicolumn{2}{|c|}{$\begin{array}{c}\mathrm{LLS}+\mathrm{GRD}+\mathrm{T} \\
2 \\
\end{array}$}} & \multirow{2}{*}{\multicolumn{2}{|c|}{ LLS+T2 }} & \multirow{2}{*}{\multicolumn{2}{|c|}{$\mathrm{GRD}+\mathrm{T} 2$}} \\
\hline & & & \multicolumn{2}{|c|}{$\mathrm{T} 1$} & \multicolumn{2}{|c|}{$\mathrm{T} 2$} & \multicolumn{2}{|c|}{$\mathrm{T} 3$} & & & & & & \\
\hline & & & RWC & LMSI & RWC & LMSI & RWC & LMSI & RWC & LMSI & RWC & LMSI & RWC & LMSI \\
\hline ICGV 01510 & & & 48.23 & 29.1 & 38.09 & 21.56 & 31.9 & 12.98 & & & & & & \\
\hline SGV AWI.0801 & & & 49.59 & 41.8 & 42.09 & 15.17 & 26.95 & 8.67 & & & & & & \\
\hline SGV AWI.0802 & & & 49.72 & 22.4 & 44.02 & 15.61 & 29.1 & 8.44 & & & & & & \\
\hline SGV AW .S6 & & & 61.47 & 24 & 37.92 & 14.4 & 28.95 & 5.91 & & & & & & \\
\hline Abutalata & 2.75 & 3 & 55.69 & 49.5 & 34.82 & 27.62 & 27.05 & 23.19 & 9.29 & 2.11 & 5.43 & 25.13 & 13.39 & 6.22 \\
\hline $\mathrm{C} 1$ & 2.75 & 2 & 40.47 & 29.3 & 19.42 & 14.39 & & & 9.33 & 1.12 & 6.74 & 22.85 & 14.49 & 5.22 \\
\hline $\mathrm{C} 10$ & 2.25 & 3.75 & 46.01 & 31.45 & 30.82 & 19.41 & & & 10.66 & 1.23 & 4.7 & 21.84 & 20.1 & 3.2 \\
\hline C11 & 2.5 & 4 & 45.63 & 27.3 & 28.49 & 17.08 & & & 9.63 & 1.53 & 2.7 & 16.79 & 18.69 & 2.48 \\
\hline $\mathrm{C} 12$ & 2.75 & 3.5 & 47.97 & 30.55 & 31.45 & 15.68 & & & 9.9 & 1.31 & 7.71 & 19.27 & 16.35 & 2.97 \\
\hline $\mathrm{C} 2$ & 3.5 & 3 & 50.92 & 36.15 & 23.89 & 12.13 & & & 8.68 & 1.62 & 5.46 & 24.56 & 15.47 & 2.66 \\
\hline $\mathrm{C} 3$ & 2.5 & 5.25 & 44.48 & 39.85 & 27.05 & 15.03 & & & 8.51 & 1.96 & 2.9 & 20.93 & 12.15 & 3.93 \\
\hline $\mathrm{C} 4$ & 3 & 4.75 & 49.01 & 26 & 27.42 & 11.81 & & & 8.94 & 1.01 & 3.03 & 22.14 & 16.03 & 2.76 \\
\hline $\mathrm{C} 5$ & 3 & 4.75 & 59.11 & 28.55 & 31.85 & 9.08 & & & 10.71 & 1.35 & 4.86 & 21.83 & 21.25 & 2.48 \\
\hline C6 & 2.75 & 4.75 & 37.39 & 42.05 & 28.85 & 22.48 & & & 10.2 & 1.51 & 3.97 & 27.04 & 20.81 & 3.72 \\
\hline $\mathrm{C} 7$ & 3 & 4.75 & 46.49 & 22.85 & 30.65 & 12.91 & & & 8.84 & 1.49 & 4.48 & 20.11 & 15.63 & 4.02 \\
\hline $\mathrm{C} 8$ & 3 & 3.75 & 48.18 & 30.5 & 29.92 & 15.93 & & & 10.87 & 1.53 & 5.04 & 12.52 & 18.85 & 2.87 \\
\hline $\mathrm{C} 9$ & 2.5 & 3.5 & 49.84 & 40.05 & 31.74 & 14.37 & & & 9.65 & 1.28 & 4.53 & 26.43 & 15.13 & 3.09 \\
\hline SGV ER 10003 & 3 & & 51.16 & 25.4 & 42.22 & 12.01 & 21.55 & 5.48 & 8.71 & 1.93 & 3.79 & 30.68 & 12.01 & 5.09 \\
\hline SGV ER 10004 & & 2.25 & 48.46 & 33.3 & 42.35 & 15.45 & 21.1 & 10.35 & & & & & 20.51 & 4.67 \\
\hline SGV ER 10009 & & 2.5 & 60.23 & 25.15 & 38.75 & 17.57 & 25.5 & 5.95 & & & & & 28.17 & 4.66 \\
\hline SGV AWI.0803 & 3 & & 55.22 & 23 & 43.59 & 15.92 & 30.25 & 5.5 & & & & & & \\
\hline SGV AWI.0804 & 3 & & 58.37 & 31.75 & 43.66 & 16.68 & 37.8 & 13.06 & & & & & & \\
\hline LSD & 1.11 & 1.73 & 15.47 & 23.63 & 9.41 & 15.12 & 13.78 & 7.23 & 3.6 & 0.76 & 2.45 & 12.04 & 7.88 & 2.92 \\
\hline
\end{tabular}

LLS Score: Late leaf spot severity at harvest; GRD Score: groundnut rosette disease severity at harvest; T1: 80\% of soil field capacity; T2: $60 \%$ of soil field capacity; T3: $40 \%$ of soil field capacity; RWC: Relative water content; LMSI: Leaf membrane stability index; Pod wt: Pod weight (g).

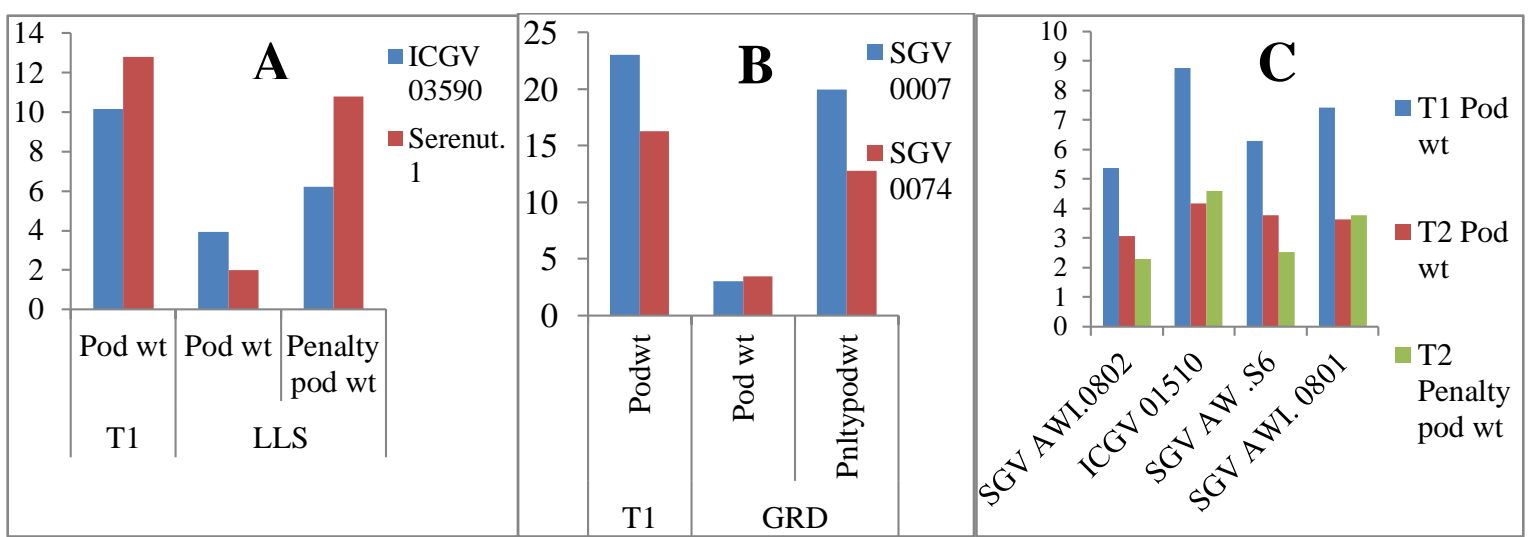

Figure 1:-Yield and yield penalty associated with single resistance to biotic and abiotic stress: A. yield and yield penalty associated with late leaf spot resistance, B. yield and yield penalty associated with groundnut rosette disease resistance and C. yield and yield penalty assocaited with tolerance to drought 


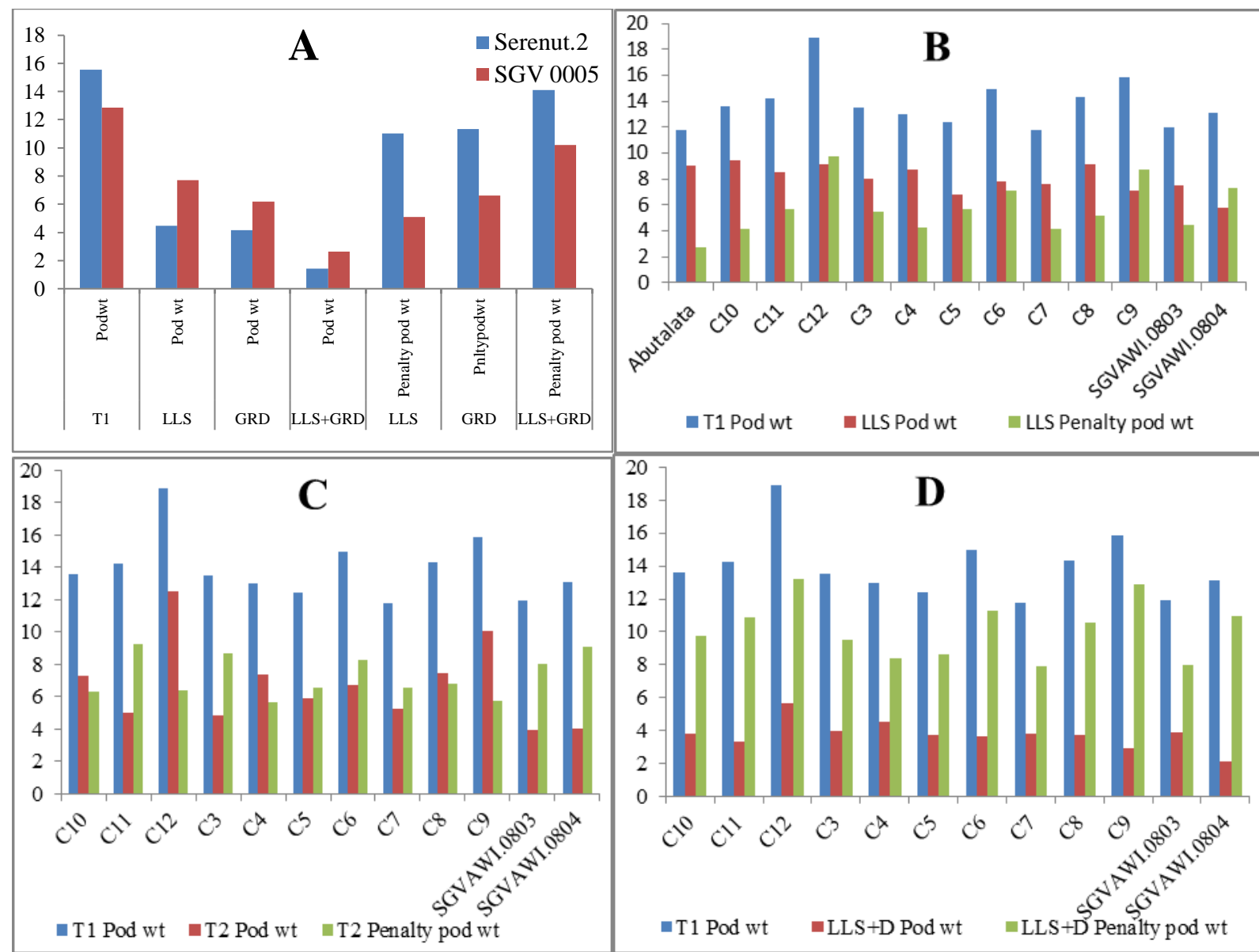

Figure 2:-Yield and yield penalty associated with double resistance to biotic and abiotic stress: A. under LLS, GRD and LLS+GRD, B. Yield and yield penalty associated with double resistance to LLS+D under LLS, 2.C. Yield and yield penalty associated with double resistance to LLS+D under drought and 2.D. Yield and yield penalty associated with double resistance to LLS+D under LLS+D

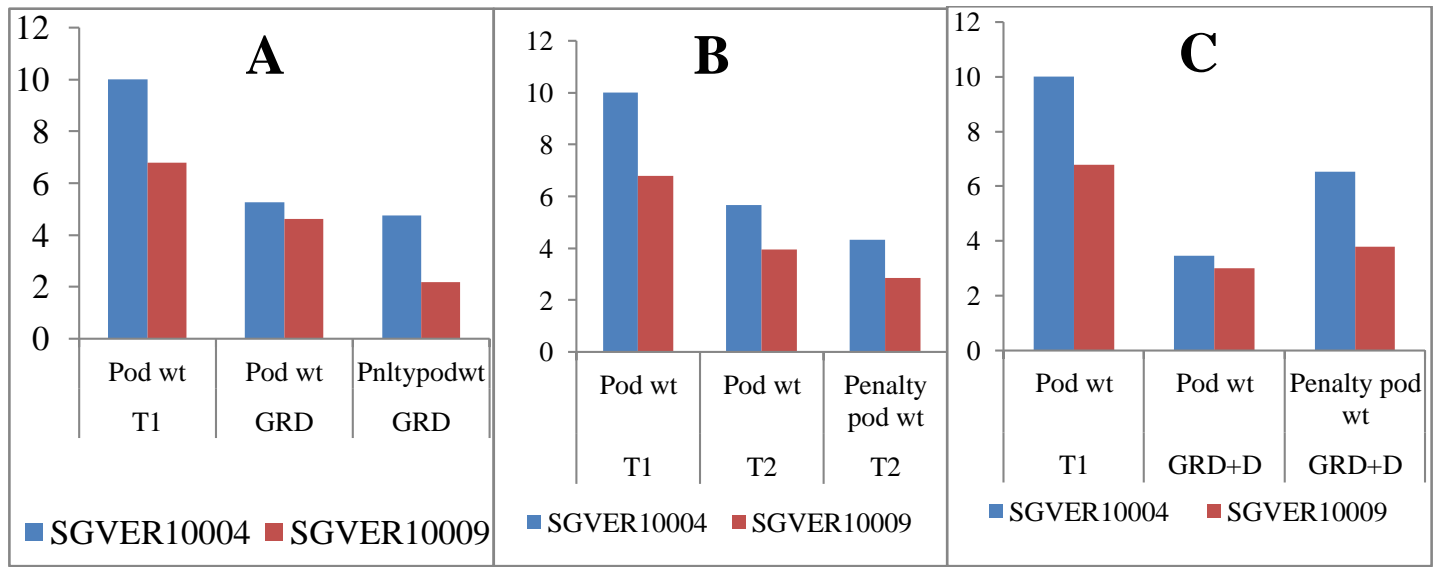

Figure 3:-Yield and yield penalty associated with double resistance to GRD+DA. under GRD,.B. under drought and 3.C. under GRD+D 


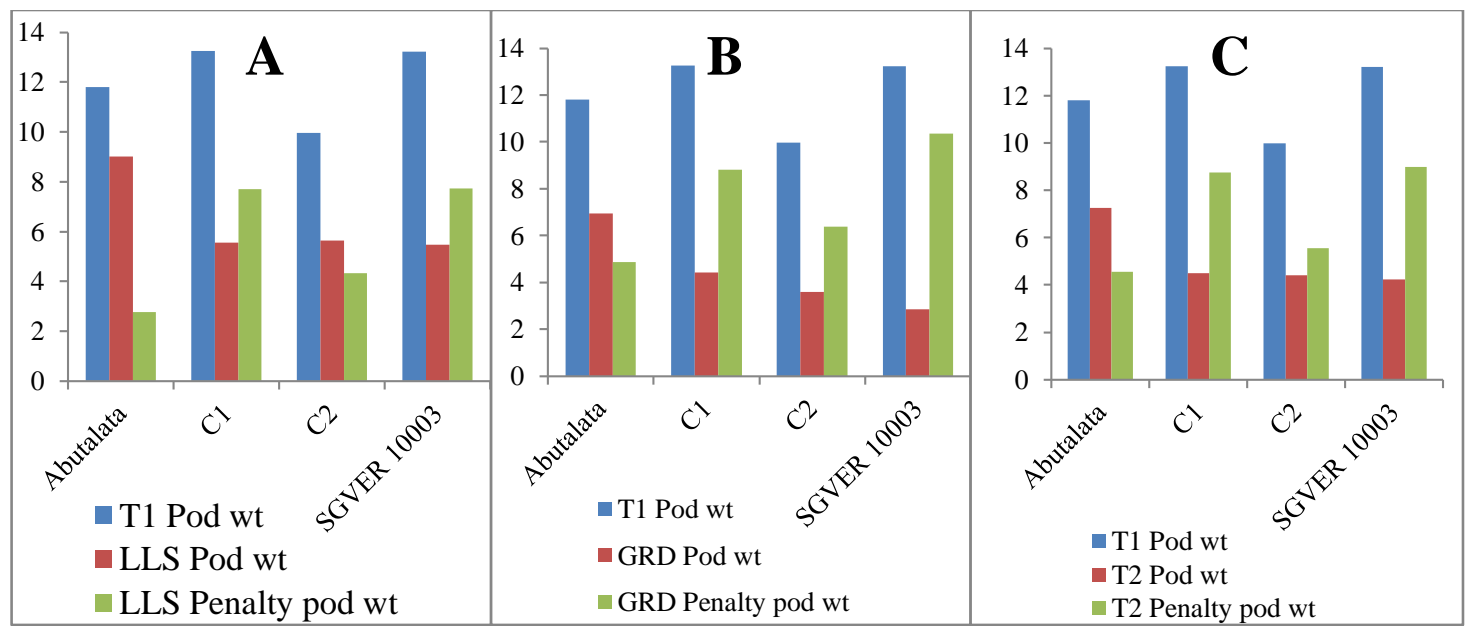

Figure 4:-Yield and yield penalty associated with multiple resistance to LLS+GRD+D

A. under LLS, B. GRD and C. under D

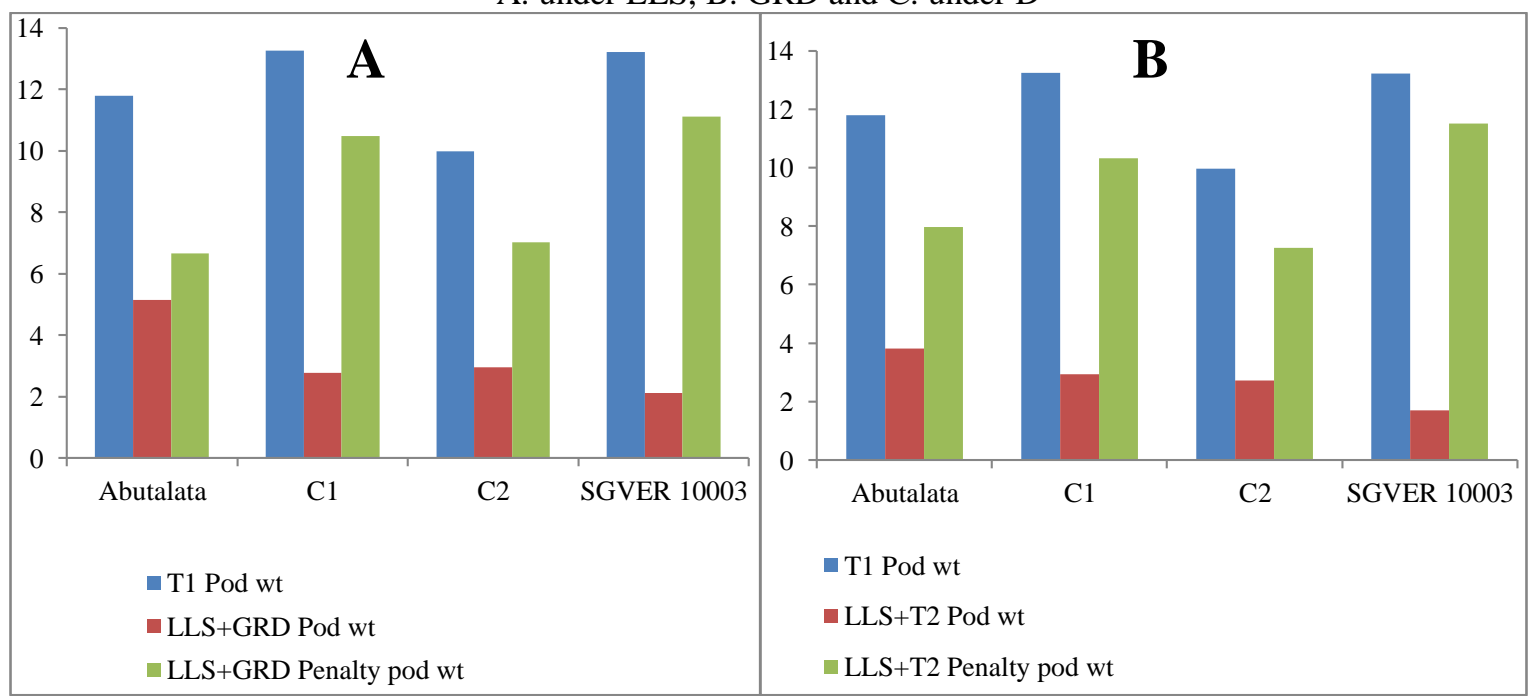

Figure 5:-Yield and yield penalty associated with multiple resistance to LLS+GRD+D

A. LLS+GRD and B under LLS+D

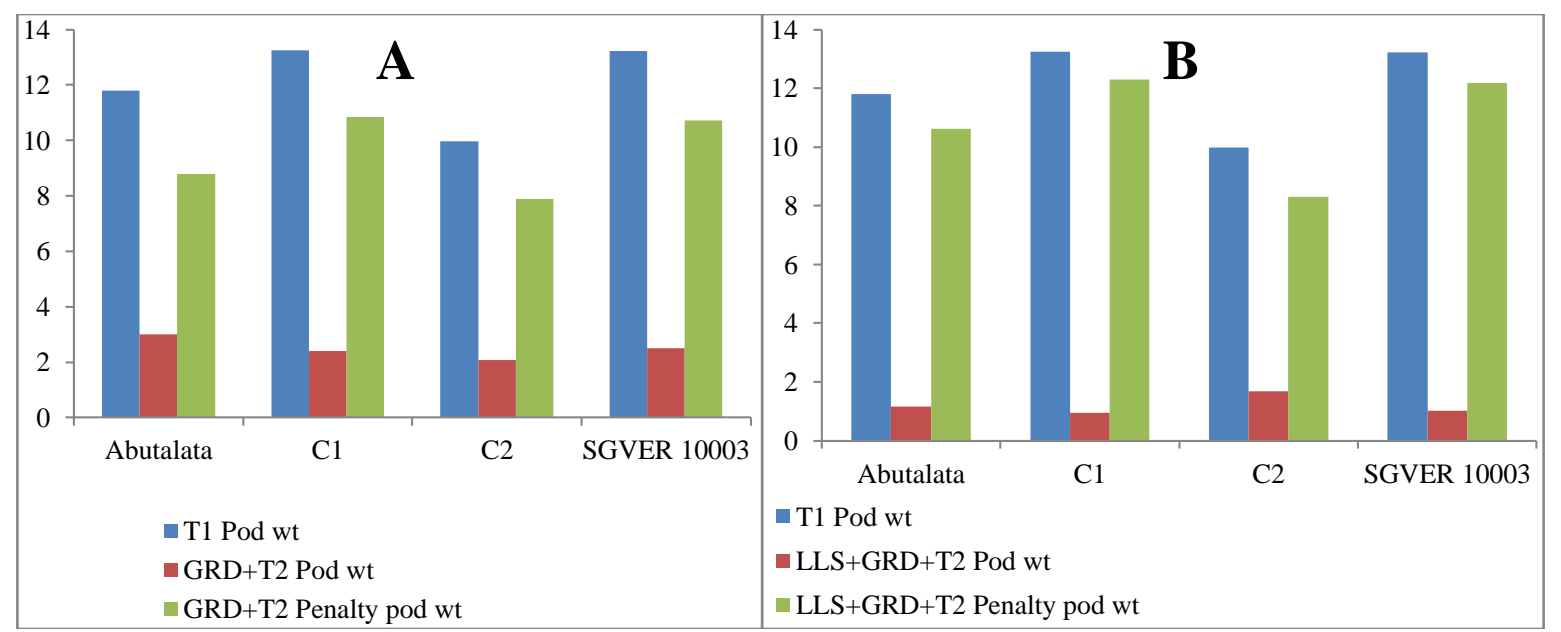

Figure 6:-Yield and yield penalty associated with multiple resistance to LLS+GRD+D

A. GRD+D and B. under LLS+GRD+D 
3.5 Means for yield penalty associated with resistance to late leaf spot, rosette and drought tolerance

The highest yield penalty of pod weight (19.98) among single resistance was recorded by SGV 0007 with GRD (Fig 1.B). It was observed that the GRD alone was responsible for higher yield penalty compared to the combinations, this could be due to GRD being an active viral disease which reduced vegetative growth of the plant, thus decreased the yield potential while, the diseases combinations are contradicted and reduced the severity of each other which did not affect yield as much as in single infestation, such a mechanism was described in Agrios (2005). Reduction in pod dry weight by GRD infested has been widely reported (Wilson, 2014). This meant that as the severity of the disease increased, the yield decreased significantly through the significant negative effects of GRD on both the morphological and reproductive growth of groundnut (Usman, 2013).

In the double resistance to LLS+GRD the high yield penalty (14.1) observed in Serenut.2 (Fig 2.A) and C12 showing (13.2) yield penalty in the LLS+D (Fig 2.D) indicated high yield penalty in double resistance. The C1 and SGV ER 10003 under LLS+GRD+D showed yield penalty with values of 12.3 and 12.2 respectively (Fig 5.B) indicating high yield penalty under high stress of the component resistance suggesting their energetic drain involved in making and maintaining a structural or chemical defense. The assumption is that costs accumulate by allocation due to diversion of energy and resources away from reproductive function. The result was in accordance with Santa cruz et al. (2014) who studied the effects of two genomic introgressions on southern leaf blight (SLB) resistance on several agronomic traits including disease resistance and yield in inbred and hybrid materials under infected and disease free conditions and reported that both introgressions might confer a yield cost even in the absence of SLB, and introgression of 6A gene was associated with a statistically significant reduction in yield. This confirmed that the yield cost is associated with the resistance phenotype rather than with linkage drag. In a barley experiment, that was heavily infected with an avirulent B graminis hordei had 7\% lower grain yield and $4 \%$ smaller grains than uninoculated control plants (Smedegaard and Stølen, 1981).

The low yield penalty (2.3) of single resistance was recorded by drought tolerant genotype (SGV AWI.0802) (Fig 1.C) under drought stress indicating the low effect of drought tolerance on yield. The low yield penalty (2.17) of double resistance to GRD+D was observed for SGV ER 10009 at GRD (Fig 3.A), (2.8) under drought (Fig 3.B) and (3.8) under GRD+T2 (Fig 3.C). As predicted yield penalty was high for multiple resistance under the combination of LLS+GRD+D. C2 showed the lowest (8.3) yield penalty under combination (Fig 6.B). Indicating the ability of genotypes to balance the allocating of the nutrition between resistance and yield and confirming the hypothesis that not all resistant genes are costly (Kolster et al., 1987). Similarly, Jorgensen and Jensen (1990) reported that no cost was associated with ten genes of resistances to barley powdery mildew.

Interrelationships among diseases indexes, drought, yield and yield penalty

The results of correlation analysis among the traits studied are presented in Table 4.

Table 4:-Correlation of yield, yield penalty, drought and diseases traits

\begin{tabular}{|c|c|c|c|c|c|c|}
\hline Traits & Pod wt & RWC & Yield Penalty & LMSI & LLS at harvest & GRD at harvest \\
\hline Pod wt & - & & & & & \\
\hline RWC & $-0.42^{*}$ & - & & & & \\
\hline Yield Penalty & -0.07 & 0.18 & - & & & \\
\hline LMSI & -0.30 & -0.23 & -0.08 & - & & \\
\hline LLS at harvest & 0.02 & $-0.38^{*}$ & $-0.45^{* *}$ & 0.02 & - & \\
\hline GRD at harvest & -0.04 & -0.09 & 0.01 & -0.12 & -0.09 & - \\
\hline
\end{tabular}

Pod wt: Pod weight (g); RWC: Relative water content; LMSI: Leaf membrane stability index; $* *=$ Significant at $.01 ; *$ Significant at .05 .

Relative water content (RWC) showed positive weak correlation with yield penalty $(r=0.18)$ indicating that the tolerance to drought with the increasing RWC had negative effect on yield which confirmed that yield penalty by drought tolerance on groundnut as genotypes spend a lot of energy in the resistance/tolerance to drought instead of yield. Similarly, Mafakheri et al. (2010) studied the effect of drought stress on chlorophyll content and yield characteristics in three varieties of chickpea with four watering regimes and reported up to $66 \%$ yield penalty under drought stress conditions. Yield penalty showed positive weak correlation $(r=0.01)$ with groundnut rosette disease indicating that the resistance to GRD was costly to the yield. 
The highly significant $(\mathrm{P}<0.01)$ negative association of LLS at harvest with yield penalty $(\mathrm{r}=-0.45)$ indicated that LLS resistance was not costly to the yield suggesting that 'stacking' of LLS resistance within a variety may not increase yield costs. Similar results were obtained by James et al. (2010) who studied costs of disease resistance and found lines containing three resistance to septoria did not exhibit greater yield losses.

\section{Conclusion:-}

There was variation in the yield and yield penalty among the 28 groundnut genotypes which could be used in selecting parental lines for improving yield and resistance to the late leaf spot, rosette diseases and drought. There was, however, high yield penalty among single, double and multiple resistance recorded by some cultivars such as SGV 0007, Serenut.2, C12, C1 and SGV ER 10003. This high yield penalty under stress indicate the energy drain involved in defense but there was also low yield penalty among some cultivars indicating the ability to balance the sharing of the resources between resistance and yield. Yield penalty was positively associated with resistance to GRD and drought tolerance and negative associated with LLS resistance. The genotypes with low penalty could be used in multiple disease and drought affected areas.

\section{Acknowledgements:-}

Regional Universities Forum for Capacity Building in Agriculture (RUFORUM), SHARE Intra-ACP, Carnegie Corporation of New York provided financial support for this study. National Semi Arid Resources Research Institute (NaSARRI, Uganda) and National Crop Research Resources Institute (NaCRRI) provided the study facilities.

\section{References:-}

1. Agrios G. N. (2005): Plant Pathology. 5th ed. Elsevier Academic Press. Burlington, M. A, USA.

2. Anderson, W. F., Wynne, J. C. and Green, C. C. (1986): Potential for incorporation of early and late leaf spot resistance in peanut, Abstr. Plant Breeding 97:163-170.

3. Babu V. R, Rao D. V. M. (1983): Water Stress Adaptations in the Groundnut (Arachis hypogaea L.) - Foliar Characteristics and Adaptations to Moisture Stress. Plant Physiol Biochemis. 10: 64-80.

4. Bergelsen, J. and Purrington, C. B. (1996): Surveying patterns in the cost of resistance in plants. Amer Nauralistt, 148: 536-558.

5. Bhagsari A.S., Brown R.H. and Schepers J.S. (1976): Effect ofmoisture stress on photosynthesis and some related physiological characteristics in peanuts. Crop Sci. 16: 712-715.

6. BSA, (2012): Beschreibende Sortenliste Getreide, Mais, € Ol- und Faserpflanzen, Leguminosen, Rüben, Zwischenfrüchte. 2013. Bundessortenamt, Hannover.

7. Gonzalez L. and Gonzalez-Vilar M. (2001): Determination of Relative Water Content In: Handbook of Plant Ecophysoilogy Techniques, Reigosa Roger, M.J. Ed. Springer, Netherlands, ISBN; 978-0-7923-6, $207-212$.

8. Gummert, A., Ladewig, E., Bürcky, K., and Bernward, M. (2015): Variety resistance to Cercospora leaf spot and fungicide application as tools of integrated pest management in sugar beet cultivation e A German case study. Crop Protection, 72, 182-194. https://doi.org/10.1016/j.cropro.2015.02.024.

9. Hamidou, F., Halilou, O., and Vadez, V. (2012): Assessment of Groundnut under Combined Heat and Drought Stress . Agronomy and Crop Science., 2012, 30-68.

10. Heil M. (2002): Baldwin I T: Fitness costs of induced resistance emerging experimental support for a slippery concept. Trends Plant Sci., 7:61-67.

11. Hemantkumar, N. (2005): Characterization of groundnut (Arachis hypogaea L.) germplasm in relation to major foliar pests and diseases. Saurashtra University.

12. Ibrahim Y. J. N. R. (2010): Screening of groundnuts (Arachis hypogaea L.) for resistance to early and late leaf spots, master of science thesis crop protection, plant pathology. Nkrumah University.

13. ICRISAT. (1995): Screening methods and sources of Resistance to Rust and Late Leaf spot of Ground. International Crops Research Institute for the Semi-Arid Tropics (ICRISAT). Information Bulletin No 47. Patencheru, India.

14. Iqbal, S, and Bano A. (2009): Water stress induced changes in antioxidant enzymes, membrane stability and seed protein profile of different wheat accessions. African Journal of Biotechnology, 8, 23, 6576-6587. https://doi.org/http://www.academicjournals.org/AJB

15. James, L., Smith, J., Paveley, N., Mur, L., and Brown, J. (2010): Project Report No . 557 Screening for. costs of disease resistance. 
16. Jorgensen. J. H. and H. P. Jensen. (1990): Effect of "unnecessary" powdery mildew resistance genes on agronomic properties of spring barley. Norsk Land bruks forsking, (suppl 9):125-130.

17. Kambiranda D. M, Vasanthaiah H. K. N, Katam R, Ananga A, Basha S, Naik K. (2011): Impact of Drought Stress on Groundnut (Arachis hypogaea L.) Productivity and Food Safety. In: Vasanthaiah HKN and Kambiranda D, ed. Plants and environment, In Tech, Available from: http://www.intechopen.com/.

18. Kayondo S. I., P. R. Rubaihayo, B. R. Ntare1, P. T. Gibson, R. Edema, A. Ozimati and Okello D. K. (2014): Genetics of resistance to Groundnut rosette disease. African Crop Science Journal. 22, No. 1, pp. 21 - 29.

19. Knauft D. A., Wynne J.C. (1995): Peanut breeding and genetics. Advances in Agronomy 55:393-445.

20. Kolster P. and L. M. Stolen. (1987): Barley isolates with genes for resistance to Erysiphe graminis f. sp. hordei in the recurrent parent.'Siri'. Crop Sci, 98:79-82.

21. Lynch, R. E. (1990): Resistance in peanut to major arthropod pests. Fla. Entomol. 73, 422-445.

22. Mafakheri, A., Siosemardeh, A., Bahramnejad, B., Struik, P. C., and Sohrabi, Y. (2010): Effect of drought stress on yield, proline and chlorophyll contents in three chickpea cultivars. Australian Journal of Crop Science, 4, 8, 580-585.

23. Maiti R. K. (2002): About the peanut crop in: R. K. Maiti and P. Wesche-Ebeling. Eds., The Peanut (Arachis hypogaea L.) Crop, Science Publishers, Inc, Enfield. pp. 1-11.

24. Mechelke, W., (2000): Züchtungs- und Sortenstrategien zur Resistenz bei Zuck- errüben gegenüber Cercospora beticola. Zuckerind 125, 688. 692.

25. Mohammed, K. E., Afutu Emmanuel, Odong, T. L., Okello, D. K., Nuwamanya, E., Grigon, O., R. Rubaihayo., Okori, P. (2018): Assessment of Groundnut (Arachis hypogaea L.) Genotypes for Yield and Resistance to Late Leaf Spot and Rosette Diseases. Journal of Experimental Agriculture International, 21,5.https://doi.org/10.9734/JEAI/2018/39912.

26. Mugisa I. O, Karungi J, Akello B, Ochwo- Ssemakula M. K. N, Biruma M, Okello DK, Otim G. (2016): Determinants of groundnut rosette virus disease occurrence in Uganda. Crop Protection. 79:117- 123.

27. Nigam S. N, Dwivedi S. L, Rao Y. L. C, Gibbons R. W. (1991): Registration of ICGS-1 peanut cultivar. Crop Science. 31, 5:1382- 1383.

28. Okello D. K, Okori P, Puppala N, Ureta BB, Deom CM, Ininda J, Anguria P, Biruma M, Asekenye C. (2014): Groundnuts seed production manual for Uganda. National Agricultural Research Organisation, Entebbe. ISBN: 978-9970-401-12-3.

29. Okello D. K., M. Biruma and Deom C. D. (2010): Overview of groundnut research in Uganda past present and future. Africa Journal Biotechnology. 9: 6448-6459.

30. Okello D. K., E. Monyo, C. M Deom, J. Ininda and Oloka H. K. (2013): Groundnuts production guide for Uganda, recommended practices for farmers: National Agricultural Research Organization, Entebbe. ISBN: 978-9970-401-06-2.

31. Payne R. W, Murray D. A, Harding S. A. (2013): An Introduction to GenStat Command language (16 ${ }^{\text {th }}$ Edition). VSN International, Hemel Hempstead, UK.

32. Reddy T. Y, Reddy V. R, Anbumozhi V. (2003): Physiological responses of amelioration: a critical review. Plant Growth Regulation. 41:75-88.

33. Sairam RK. (1994): Effect of moisture stress on physiological activities of two contrasting wheat genotypes. Ind. J. Exp. Biol. 32: 594-597.

34. Santa-cruz, J. H., Kump, K. L., Arellano, C., Goodman, M. M., Krakowsky, M. D., Holland, J. B., and Balintkurti, P. J. (2014): Yield Effects of Two Southern Leaf Blight Resistance Loci in Maize Hybrids. Crop Sci, 54, 1, 882-894. https://doi.org/10.2135/cropsci, 2013.08.0553.

35. Shinde B. M., and Laware, S. L. 2(014): Screening of groundnut (Arachis hypogaea L.) varieties for drought tolerance through physiological indices. Environmental Research and Development, 9, 2, 375-381.

36. Smedegaard-Petersen V, Stølen O. (1981): Effect of energy-requiring defense reactions on yield and grain quality in a powdery mildew resistant barley cultivar. Phytopathol, 71:396-399.

37. Subrahmanyam P. D, Donald M, Waliyar FR, Nigam L. J, Gibbons S. N, Rao R. W, Singh V. R, Pande A. K. S, Reddy P. M, Rao S. P. V. (1995): Screening methods and sources of resistance of rust and late leaf spot of groundnut. Inf. Bull. ICRISAT, Patancheru, Andhra Pradesh, India. 47:19.

38. Subrahmanyam P., J. P. Moss, D. McDonald, P.V. SubbaRao and Rao,V. R. (1985): Resistance to leaf spot caused by Cercosporidium personatum in Wild Arachis species, Plant Disease. 69. 951-954.

39. Suther D. M, Patel M. S. (1992): Yield and Nutrient Absorption by Groundnut and Iron Availability in Soil as Influenced By Lime and Soil Water. J Indian Society Soil Sci 40: 594-596.

40. Usman, A. (2013): Genetic analysis of resistance to rosette disease of groundnut (Arachis hypogaea L.). PhD Thesis. University of Ghana, Legon. Ghana. 
41. Wambi .W., P. Tukamuhabwa, N. Puppali, D. K. Okello, R. G. Nalugo and N. A. Kaaya. (2014): Narrow sense heritability and gene effects for late leaf spot resistance in valencia groundnuts. African Crop Science Journal, 22:327 - 336 .

42. Wilson, C. R. (2014): Applied Plant Virology. CABI Press, Wallingford, UK.

43. Zavaleta, E. S., Pasari, J. R., Hulvey, K. B., Tilman, G. D. (2010): Sustaining multiple ecosystem functions in grassland communities requires higher biodiversity. PNAS 107, 1443-1446. 